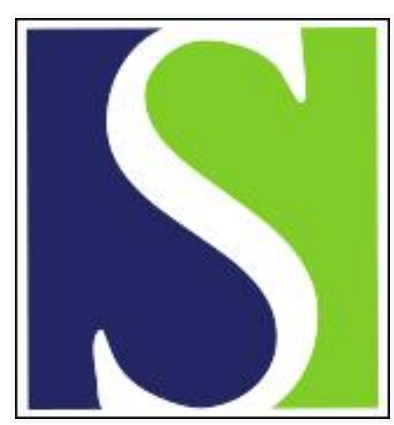

Scand J Work Environ Health 1993;19(1):55-62

https://doi.org/10.5271/sjweh.1503

Issue date: $01 \mathrm{Feb} 1993$

Hepatic metabolism of toluene after gastrointestinal uptake in humans.

by Baelum J, Molhave L, Honore Hansen S, Dossing M

Affiliation: Institute of Environmental and Occupational Medicine, University of Aarhus, Denmark.

This article in PubMed: www.ncbi.nlm.nih.gov/pubmed/8465173

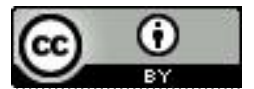




\title{
Hepatic metabolism of toluene after gastrointestinal uptake in humans
}

\author{
by Jesper Bælum, MD, ${ }^{1}$ Lars Mølhave, PhD, ${ }^{1}$ Steen Honoré Hansen, $\mathrm{PhD},{ }^{2}$ Martin Døssing, $\mathrm{MD}^{3}$
}

\begin{abstract}
BÆLUM J, MØLHAVE L, HONORÉ HANSEN S, DØSSING M. Hepatic metabolism of toluene after gastrointestinal uptake in humans. Scand J Work Environ Health 1993;19:55 - 62. The metabolism of toluene and the influence of small doses of ethanol were measured in eight male volunteers after gastrointestinal uptake, the toluene concentration in alveolar air and the urinary excretion of hippuric acid and ortho-cresol being used as the measures of metabolism. During toluene exposure to $2 \mathrm{mg} \cdot \min ^{-1}$ for $3 \mathrm{~h}$ the alveolar toluene concentration was 0.07 (range $\left.0-0.11\right) \mathrm{mg} \cdot \mathrm{m}^{-3}$; exposure to $6 \mathrm{mg} \cdot \mathrm{min}^{-1}$ for $30 \mathrm{~min}$ increased the alveolar concentration to 0.9 (range $\left.0.03-2.6\right) \mathrm{mg} \cdot \mathrm{m}^{-3}$. Ingestion of $0.08,0.16$, and $0.32 \mathrm{~g}$ of ethanol per kilogram of body weight during toluene exposure of $2 \mathrm{mg} \cdot \mathrm{min}^{-1}$ increased the alveolar concentration within $10 \mathrm{~min}$, and maximal alveolar concentrations of 5 (SD 3), 24 (SD 11), and 39 (SD 28) $\mathrm{mg} \cdot \mathrm{m}^{-3}$ were reached after 30, 60, and $90 \mathrm{~min}$ for the three doses, respectively. Hippuric acid excretion was only decreased by an ethanol dose of $0.32 \mathrm{~g} \cdot \mathrm{kg}^{-1}$. Very low doses of ethanol inhibit toluene metabolism, and the procedure is sensitive enough to measure metabolic interactions between solvents and other xenobiotics in humans.
\end{abstract}

Key terms: alveolar air, ethanol, hepatic extraction, interaction, metabolites.

Inhalation is the usual route of exposure to organic solvents, while dermal exposure only contributes a small amount to the solvent load. The metabolism of most solvents is carried out by the liver, and at the usual levels of occupational exposure the hepatic clearance of most solvents approaches liver blood flow corresponding to a hepatic extraction ratio (the ratio between the amount metabolized and the delivery to the liver) close to unity (1). Well-known examples are toluene and some of the halogenated hydrocarbons $(2,3)$.

In inhalation studies liver metabolism has been estimated either from the total blood clearance during and after experimental exposure or from the measurement of the urinary excretion of metabolites. The studies of metabolic interactions between organic solvents or between solvents and drugs have given various results $(2,4-6)$, probably due to the large interindividual variations in pharmacokinetic parameters and nonspecific metabolites of several substances.

When the hepatic metabolism of solvents is being studied in humans, gastrointestinal application has some theoretical advantages over inhalation. In healthy subjects the blood from the gastrointestinal

1 Institute of Environmental and Occupational Medicine, University of Aarhus, Århus, Denmark.

2 Royal Danish School of Pharmacy, Copenhagen, Denmark.

3 Medical Department P, Copenhagen Municipal Hospital, Bispebjerg, Copenhagen.

Reprint requests to: Dr J Bælum, Institute of Environmental and Occupational Medicine, Universitetsparken Building 180, DK-8000, Århus C, Denmark. channel from cardia to rectum is almost exclusively drained via the porta system to the liver before reaching systemic circulation. If the posthepatic solvent concentration is measured, the hepatic extraction ratio can be estimated. If this ratio is close to unity, then minute changes in metabolism will cause large relative changes in the hepatic venous concentration and, subsequently, also in the mixed venous blood and alveolar air concentrations.

Human data on the gastrointestinal uptake of toluene are not available, but rat studies on toluene have shown complete uptake, which, however, is slower than pulmonary uptake (7).

The objective of the present paper was to describe a method using toluene as a model substance and small doses of ethanol as the interacting factor.

\section{Subjects and methods}

Two studies were carried out on male volunteers. Study A constituted the first experience with the experimental method, and a successive series of exposures was carried out. Four healthy male subjects aged 24 to 37 years with body weights between 69 and $83 \mathrm{~kg}$ participated.

Study B was a balanced study in which the interaction of small doses of ethanol on toluene metabolism was measured. The four male subjects who participated were between 24 and 29 years of age with body weights ranging from 72 to $84 \mathrm{~kg}$.

All eight subjects were nonsmokers without any history of liver disease or regular drug consumption, and they were moderate users of alcohol $(<40 \mathrm{~g}$ of pure alcohol per week). Before entering the study all of the subjects were given a medical examination. 
Table 1. The schedules of exposure in study A.

\begin{tabular}{|c|c|c|c|}
\hline Exposure & Toluene & Ethanol & $\begin{array}{l}\text { Subjects } \\
\text { exposed }\end{array}$ \\
\hline I and II & $\begin{array}{l}2.3 \mathrm{mg} \cdot \mathrm{min}^{-1} \text { for } \\
4.40 \mathrm{~min}^{\mathrm{a}}\end{array}$ & - & $1,2,3$ \\
\hline III & $\begin{array}{l}6 \mathrm{mg} \cdot \mathrm{min}^{-1} \text { for } \\
30 \mathrm{~min}\end{array}$ & - & $1,2,3,4$ \\
\hline IV & $\begin{array}{l}12 \mathrm{mg} \cdot \mathrm{min}^{-1} \text { for } \\
30 \mathrm{~min}\end{array}$ & - & 4 \\
\hline v & $\begin{array}{l}2.3 \mathrm{mg} \cdot \min ^{-1} \text { for } \\
4.40 \mathrm{~min}^{\mathrm{a}}\end{array}$ & $\begin{array}{l}0.16 \mathrm{~g} \cdot \mathrm{kg}^{-1} \text { at } \\
90 \mathrm{~min} \text { and } \\
1.6 \mathrm{mg} \cdot \mathrm{min}^{-1} \cdot \mathrm{kg}^{-1} \\
\text { from } 90 \text { to } 175 \mathrm{~min}\end{array}$ & $1,2,3$ \\
\hline VI & $\begin{array}{l}2 \mathrm{mg} \cdot \mathrm{min}^{-1} \text { for } \\
180 \mathrm{~min}\end{array}$ & $\begin{array}{l}0.16 \mathrm{~g} \cdot \mathrm{kg}^{-1} \text { at } \\
60 \mathrm{~min}\end{array}$ & 4 \\
\hline VII & $50 \mathrm{mg}$ bolus & $\begin{array}{l}2.4 \mathrm{mg} \cdot \mathrm{kg}^{-1} \\
\mathrm{~min}^{-1} \text { tor } 3 \mathrm{~h}\end{array}$ & 2 \\
\hline
\end{tabular}

a $4-40 \mathrm{~min}=$ four consecutive $40-\mathrm{min}$ periods with 5 - $\mathrm{min}$ breaks for micturition inbetween.

In addition to blood tests including serum concentrations of alanine aminotransferase, aspartate aminotransferase, bilirubin, and alkaline phosphatases the coagulation factors II, VII, and X (prothrombin time) were all normal, and none of the subjects had hepatitis $\mathrm{B}$ antibodies.

Before each examination the subjects had avoided alcohol for the last $3 \mathrm{~d}$, and sports activities had been avoided within the last $24 \mathrm{~h}$. On the day of the examination they were told to avoid milk and products containing benzoic acid at breakfast. At least $7 \mathrm{~d}$ should have passed since any acute illness or intake of medicine.

\section{Experimental design}

Each subject went through a series of three to five (study A) or six (study B) examinations separated by at least $4 \mathrm{~d}$ and done single blinded.

Exposure. The basal dose rates of toluene used was equivalent to $2 \mathrm{mg} \cdot \mathrm{min}^{-1}\left(22 \mu \mathrm{mol} \cdot \mathrm{min}^{-1}\right)$ continuously for $3 \mathrm{~h}$. This oral dose was calculated to provide the liver with a dose rate corresponding to inhalation exposure to $50 \mathrm{ppm}$ in combination with light exercise $(50 \mathrm{~W})(8,9)$. The toluene was applied through a feeding tube (Flocare, $\mathrm{CH} 8$, Nutricia, Vermeeren, The Netherlands). The tube was inserted through the nose to a depth of $110 \mathrm{~cm}$, and the position in the stomach was controlled by auscultation during air insufflation.

Toluene $(180 \mathrm{mg}$ ) was dissolved in 150 or $300 \mathrm{ml}$ of a commercial tube feeding product (Nutrison, Nutricia, Vermeeren, The Netherlands). In all of the exposures except exposure I in study A, $0.4-1 \mathrm{ml}$ of an emulgator (Polysorbat $80^{\circledR}$ ) was added. The mixture was administered through the tube with the use of a variable laboratory pump (FMI mod RPP, Fluid Metering, Oyster Bay, New York, United States), and the dose rate was controlled through the continuous weighing of the container. Except for the feeding tube all surfaces in contact with the fluid were made of glass, teflon, or stainless steel in order to avoid the adsorption of toluene on the surfaces.
Study A. Table 1 shows the sequence of exposures to each subject in study A.

Toluene was given at a rate of $2.3 \mathrm{mg} \cdot \mathrm{min}^{-1}$ in four consecutive periods, each lasting $40 \mathrm{~min}$ interrupted by 5 -min breaks for micturition (equivalent to $2 \mathrm{mg} \cdot \mathrm{min}^{-1}$ for $180 \mathrm{~min}$ ). In exposure V ethanol was given as a combination of an oral bolus after 90 min of toluene exposure and a maintenance dose via the tube during the rest of the exposure. The total dose was equivalent to two alcoholic drinks $(\sim 24 \mathrm{~g}$ of pure alcohol).

Study $B$. In a randomized design the subjects in study $B$ were exposed to six conditions, consisting of toluene $\left(2.2 \mathrm{mg} \cdot \mathrm{min}^{-1}\right)$ administered in three consecutive periods, each lasting $55 \mathrm{~min}$ interupted by 5 -min breaks, and four levels of ethanol $(0,0.08$, 0.16 , and $0.32 \mathrm{~g}$ ethanol per kilogram of body weight - equivalent to $0.5,1$, and 2 usual drinks, respectively) and exposure without toluene (control) in combination with ethanol doses of 0 and $0.32 \mathrm{~g}$ $\cdot \mathrm{kg}^{-1}$. The ethanol $(96 \%)$ was diluted in orange juice and given orally in six fractions from 60 to $85 \mathrm{~min}$ after the start of the toluene or control exposure.

\section{Measurements}

Toluene in alveolar air. End expiratory air samples were collected in 250-ml glass pipettes capped with teflon-coated silicone membranes. Before the air sample was collected, the subject made a maximal inspiration and held his breath for $15 \mathrm{~s}$ to achieve equilibrium between the blood and alveolar air (10). The pipettes were preheated to $43^{\circ} \mathrm{C}$ and kept at this temperature until analysis to avoid condensation.

The concentration of toluene was measured by gas chromatography-mass spectrometry within $2 \mathrm{~h}$ after the sampling.

With the use of preheated $\left(45^{\circ} \mathrm{C}\right) 0.5-$ to $20-\mathrm{ml}$ precision sampling corporation injection syringes (Pressure Lock series) air samples were taken from the pipettes and injected directly into the heated sample container of a Tekmar model 5010 automatic desorber during the desorption phase. The desorber was connected to a Hewlett Packard 5930A gas chromatograph-mass spectrometer containing a Carbowax 20M 25-m capillary column, which was run at a constant temperature $\left(40^{\circ} \mathrm{C}\right)$ in a Hewlett Packard 5700 gas chromatograph.

Masses from 46 to 110 were sampled in the online program and stored. The identification of toluene in the mass chromatogram was based on retention times and the appearance of masses 91 and 92 . The quantification was made by calculation of the area of these mass ion peaks.

The analytical equipment was calibrated with a standard gas (AGA, Stockholm, Sweden), 6.5 (SD $0.5) \mathrm{ppm}$ of toluene, in synthetic air. The standard curve for injection between 10 and $50 \mathrm{ng}$ of toluene 
was linear with a regression coefficient $(r)$ of 0.97 . The detection limit for toluene was $1 \mathrm{ng}$, equivalent to an alveolar concentration of $0.05 \mathrm{mg} \cdot \mathrm{m}^{-3}$.

\section{Metabolites}

The urine was quantitatively sampled in seven periods. Concentrations of hippuric acid (HA) and ortho-cresol (o-cresol) were measured by high-performance liquid chromatographic methods described earlier (11).

\section{Calculations}

The area under the curve of the alveolar toluene concentration (AUC) was estimated by the trapezoid rule. In study A the tail area was estimated on the assumption of an exponential decrease in concentration (C) between the two last measurements $(n-1$ and $n$ ), giving the formula (12):

$$
\mathrm{AUC}_{\text {tail }}=\mathrm{C}_{n} / k,
$$

where $k$ was calculated as:

$$
k=-\left\{\left[\ln \left(\mathrm{C}_{n} / \mathrm{C}_{n-1}\right)\right] /\left(t_{n}-t_{n-1}\right)\right\} .
$$

In study B no tail area was calculated.

For each metabolite the rates and the cumulative excretion were calculated. By subtraction of the preexposure excretion rates the percentages of the toluene metabolized to HA could be estimated.

The hepatic extraction ratio (HE) could only be estimated indirectly, the biological available (not metabolized) dose of toluene $\left(D_{b}\right)$ being considered proportional to the AUC with factor $f$, where $D$ is the dose given and $M$ is the amount metabolized:

$$
D_{b}=D-M=D(1-\mathrm{HE})=f \cdot \mathrm{AUC} .
$$

The change in $D_{b}\left(\Delta D_{b}\right)$ was estimated by the change in HA excretion exhibited by the addition of ethanol (exposure V versus I and II) as $\left(\triangle \mathrm{HA}=\mathrm{HA}_{\mathrm{eth}}\right.$ $\left.\mathrm{HA}_{-\mathrm{eth}}\right)$ and $f$ was then:

$$
f=\left(\mathrm{HA}_{-\mathrm{eth}}-\mathrm{HA}_{\mathrm{eth}}\right) /\left(\mathrm{AUC}_{\mathrm{eth}}-\mathrm{AUC}_{-\mathrm{eth}}\right) .
$$

Under condition $x$ :

$$
\begin{aligned}
D_{h x} & =D\left(1-\mathrm{HE}_{x}\right) \\
& =\mathrm{AUC}_{x}\left[\left(\mathrm{HA}_{-\mathrm{eth}}-\mathrm{HA}_{\mathrm{eth}}\right) /\left(\mathrm{AUC}_{\text {eth }}-\mathrm{AUC}_{\text {-eth }}\right)\right],
\end{aligned}
$$

and the hepatic extraction ratio for toluene could then be calculated.

\section{Statistical analysis}

The difference between the treatments in study B was tested by an analysis of variance of repeated measurements.

Both studies were approved by the Regional Ethical Committee for Aarhus County according to the Declaration of Helsinki.

\section{Results}

Study A

Figure 1 shows the time course of the alveolar air concentration of toluene during exposure conditions I, II, III, and V. Table 2 also shows the AUC values
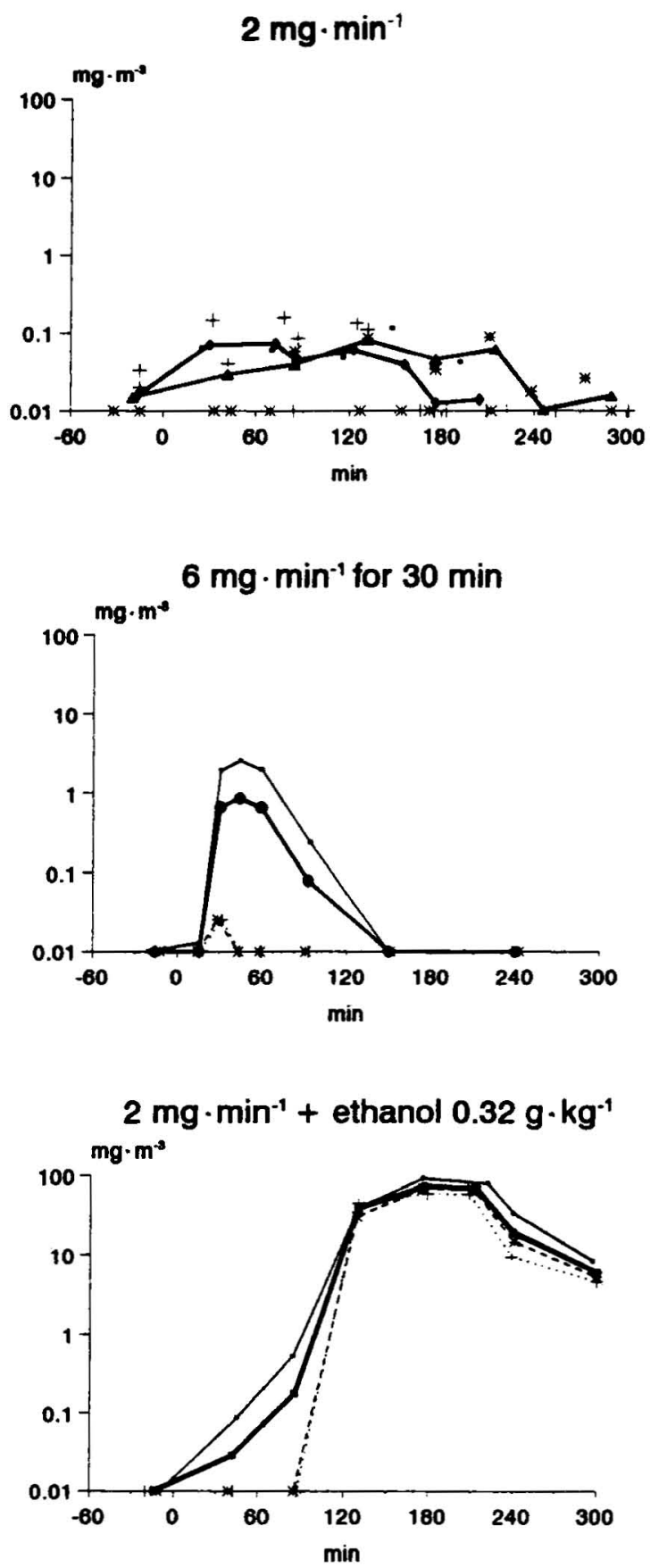

Figure 1. Time course of the alveolar concentration of toluene during and after four different exposure schedules in study A. The figures show the means (heavy lines) and the individual values of subjects 1,2 , and $3(+, *$, and $\bullet)$. In the top figure $\downarrow=$ exposure $\mathrm{I}$ and $\boldsymbol{\Lambda}=$ exposure II. 
Table 2. Maximal alveolar toluene concentration and the area under the curve (AUC), as well as the urinary excretion of metabolites in study $A$. The values are the means and the ranges of subjects 1,2 , and 3 .

\begin{tabular}{|c|c|c|c|c|c|c|c|c|c|}
\hline \multirow[t]{2}{*}{$\begin{array}{l}\text { Exposure } \\
\text { conditions }\end{array}$} & \multicolumn{2}{|c|}{$\begin{array}{c}\text { Maximal alveolar } \\
\text { toluene concen- } \\
\text { tration } \\
\left(\mathrm{mg} \cdot \mathrm{m}^{-3}\right)\end{array}$} & \multicolumn{2}{|c|}{$\begin{array}{c}\text { AUC-alveolar } \\
\text { toluene concen- } \\
\text { tration } \\
\left(\mathrm{mg} \cdot \min \cdot \mathrm{m}^{-3}\right)\end{array}$} & \multicolumn{2}{|c|}{$\begin{array}{l}\text { Hippuric acid } \\
\text { excretion } \\
\text { (mmol) }\end{array}$} & \multirow{2}{*}{$\begin{array}{c}\begin{array}{c}\text { ortho-Cresol } \\
\text { excretion } \\
(\mu \mathrm{mol})\end{array} \\
\text { Mean Range }\end{array}$} & \multicolumn{2}{|c|}{$\begin{array}{l}\text { Hepatic extraction } \\
\text { ratio }\end{array}$} \\
\hline & Mean & Range & Mean & Range & Mean & Range & & Mean & Range \\
\hline Toluene, $2 \mathrm{mg} \cdot \mathrm{min}^{-1}(\mathrm{I})$ & 0.06 & $0-0.12$ & 10 & $0-18$ & 3.7 & $3.0-4.65$ & $\begin{array}{lll}1.5 & 0.8-2.3\end{array}$ & 0.9998 & $0.9994-1.0$ \\
\hline Toluene, $2 \mathrm{mg} \cdot \mathrm{min}^{-1}$ (II) & 0.08 & $0.06-0.11$ & 13 & $0-18$ & 4.2 & $3.6-4.7$ & $1.90 .6-3.4$ & 0.9997 & $0.9994-1.0$ \\
\hline $\begin{array}{l}\text { Toluene, } 6 \mathrm{mg} \cdot \mathrm{min}^{-1} \text { for } \\
30 \mathrm{~min} \text { (III) }\end{array}$ & 0.9 & $0.03-2.6$ & 42 & $0-125$ & 1.9 & $1.9-2.1$ & $1.20 .6-1.5$ & 0.9985 & $0.995-1.0$ \\
\hline $\begin{array}{l}\text { Toluene, } 2 \mathrm{mg} \cdot \mathrm{min}^{-1} \\
\text { + ethanol, } 0.32 \mathrm{~g} \cdot \mathrm{kg}^{-1} \text { (V) }\end{array}$ & 74 & $60-93$ & 8487 & $7645-10629$ & 93.2 & $3.1-3.7$ & $2.92 .3-3.7$ & 0.78 & $0.68-0.84$ \\
\hline
\end{tabular}

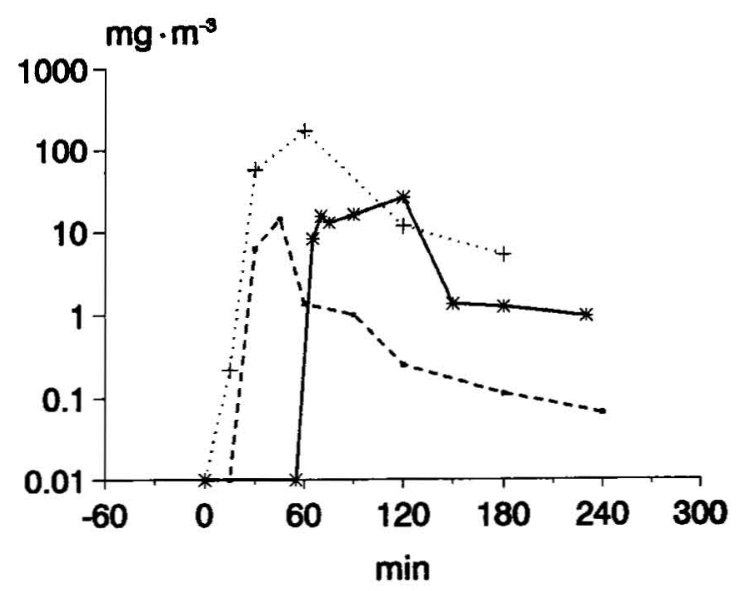

Figure 2. Alveolar concentration of toluene in subject 4 during exposure to $12 \mathrm{mg} \cdot \mathrm{min}^{-1}$ (dotted line) and $6 \mathrm{mg} \cdot \mathrm{min}^{-1}$ (dashed line) for $30 \mathrm{~min}$, as well as exposure to $2 \mathrm{mg} \cdot \mathrm{min}^{-1}$ for 180 min combined with an oral bolus of ethanol $(0.16 \mathrm{~g}$. $\mathrm{kg}^{-1}$ ) after $60 \mathrm{~min}$ of toluene exposure (solid line).

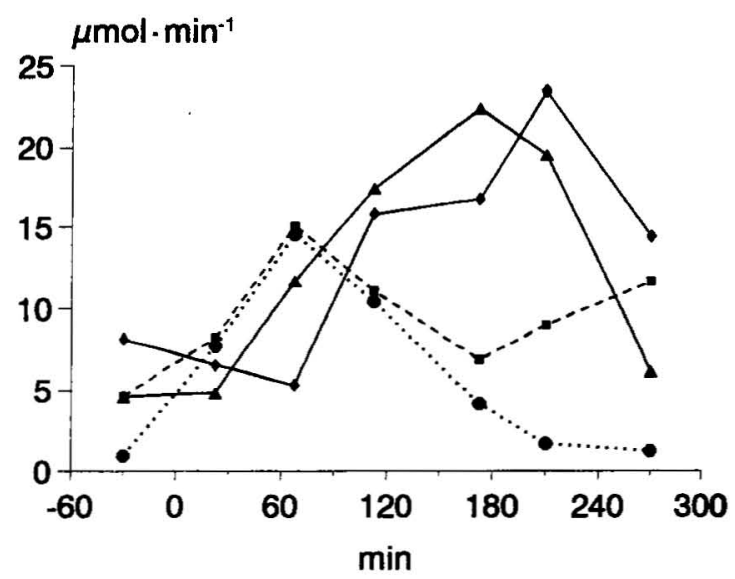

Figure 3. Excretion rate of hippuric acid (HA) during and after the four different exposures in study $A$. Each curve shows the average of the three subjects. $(\bullet=$ exposure I, $\mathbf{\Delta}=$ exposure II, $\bullet=$ exposure III $\left(6 \mathrm{mg} \cdot \mathrm{min}^{-1}\right), \boldsymbol{a}=$ exposure $\mathrm{V}+$ ethanol) and the cumulative excretion of the metabolites. During exposure to a toluene dose of $2 \mathrm{mg} \cdot \mathrm{min}^{-1}$ the concentration in alveolar air was very low, $0-$ $0.1 \mathrm{mg} \cdot \mathrm{m}^{-3}$ with AUC values up to $18 \mathrm{mg} \cdot \mathrm{min}^{-1}$ $\cdot \mathrm{m}^{-3}$.There was no significant difference between the subjects and no difference between exposures I and II. Exposure to $6 \mathrm{mg} \cdot \mathrm{min}^{-1}$ for $30 \mathrm{~min}$ caused a peak of 2.3 in one subject and $25 \mathrm{mg} \cdot \mathrm{m}^{-3}$ in another. In the other subjects only a transient and small increase in alveolar concentration was seen. In subject 4 (see figure 2) doses of 2,6 , and $12 \mathrm{mg} \cdot \mathrm{min}^{-1}$ for $30 \mathrm{~min}$ caused a peak alveolar concentration of 0,25 , and $123 \mathrm{mg} \cdot \mathrm{m}^{-3}$ and AUC values of 0,420 , and 10300 $\mathrm{mg} \cdot \min ^{-1} \cdot \mathrm{m}^{-3}$, respectively. The maximal concentrations were reached 15 to $30 \mathrm{~min}$ after the end of exposure.

Ethanol caused a considerable increase in the alveolar toluene concentration. The concentration was almost constant from 90 to $120 \mathrm{~min}$ after ingestion and decreased sharply between 30 and $60 \mathrm{~min}$ after the end of exposure. The inhibition was apparent within $5 \mathrm{~min}$ after the ingestion of a single ethanol dose of $0.16 \mathrm{~g} \cdot \mathrm{kg}^{-1}$, and the maximum was reached after $60 \mathrm{~min}$ (figure 2), followed by a sharp decrease in alveolar concentration.

When a bolus of toluene was given while the metabolism was inhibited with ethanol (exposure VII), the alveolar concentration increased after a lag time of about $15 \mathrm{~min}$, and the maximum of $3.4 \mathrm{mg} \cdot \mathrm{m}^{-3}$ was reached $45 \mathrm{~min}$ after ingestion.

The excretion of HA is shown in figure 3. The HA excretion increased steadily during exposure and decreased in the first sample thereafter. In exposure II the excretion was faster than in exposure $I$, a result suggesting an effect of the emulgator used to secure the mixing of toluene. The estimated excretion of HA corresponded to 87 (range $73-106$ ) $\%$ and 104 (range $90-114) \%$ of the dose given in exposures I and II, respectively. The $30-\mathrm{min}$ exposure caused a brief increase in the HA excretion, but it returned to the background level within $3 \mathrm{~h}$ after the exposure.

The excretion of $o$-cresol (see figure 4 ) was delayed in comparison with that of HA, and $o$-cresol continued to be excreted for more than $3 \mathrm{~h}$ after ex- 
posure. The 30-min exposure caused a constant excretion.

The ingestion of ethanol immediately decreased the HA excretion by $38 \%$. The excretion during the last hour of exposure was $67 \%$, and the total excretion was 30 (range 14-38)\% lower than in exposure II. A partial compensatory increase was seen $1 \mathrm{~h}$ after exposure.

Ethanol increased the $o$-cresol excretion by 218 (range -9 to 365 ) $\%$.

\section{Study $B$}

Figure 5 shows the time course of the alveolar concentration of toluene during the four levels of ethanol ingestion. The AUC and the amount of HA and $o$-cresol excreted during and after exposure are shown in table 3.

When no ethanol was given, the concentration of toluene was below the detection limit until the last

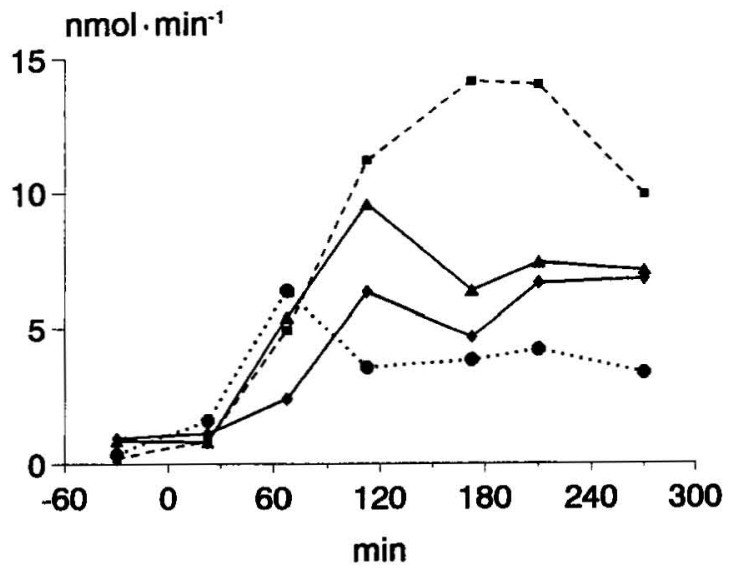

Figure 4. Excretion rate of ortho-cresol during and after the four different exposures in study $A$. $(\bullet=$ exposure $\mathrm{I}, \boldsymbol{\Delta}=$ exposure II, $\cdots=$ exposure III $\left(6 \mathrm{mg} \cdot \min ^{-1}\right), \mathbf{m}=$ exposure $\mathrm{V}+$ ethanol)
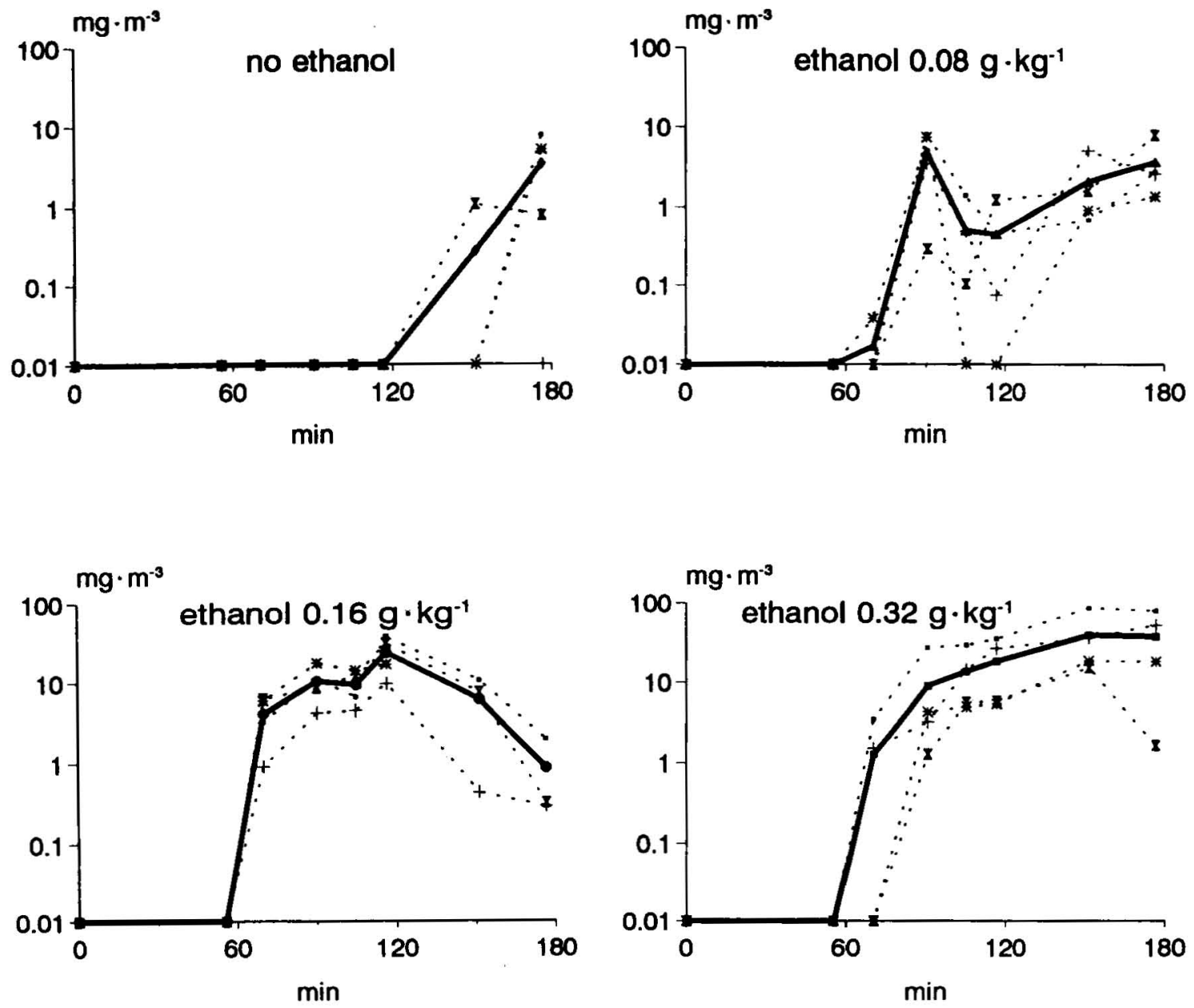

Figure 5. Alveolar concentration of toluene during exposure to a toluene concentration of $2 \mathrm{mg} \cdot \mathrm{min}^{-1}$ combined with ethanol $\left(0,0.08,0.16\right.$, and $0.32 \mathrm{~g} \cdot \mathrm{kg}^{-1)}$ given $60-85 \mathrm{~min}$ after the start of exposure. Each graph shows the mean (heavy line) and the individual values of four subjects $(\bullet,+, *, \mathbf{Z})$. 
Table 3. Area under the alveolar concentration curves $(A \cup C)$ and the total metabolite excretion during exposure.

\begin{tabular}{|c|c|c|c|c|c|c|}
\hline \multirow[t]{2}{*}{$\begin{array}{l}\text { Exposure } \\
\text { conditions }\end{array}$} & \multicolumn{2}{|c|}{$\begin{array}{c}\text { AUC alveolar toluene } \\
\text { concentration } \\
\left(\mathrm{mg} \cdot \mathrm{min}^{-1} \mathrm{~m}^{-3}\right)\end{array}$} & \multicolumn{2}{|c|}{$\begin{array}{l}\text { Hippuric acid } \\
\text { excretion } \\
\text { (mmol) }\end{array}$} & \multicolumn{2}{|c|}{$\begin{array}{c}\text { ortho-Cresol } \\
\text { excretion } \\
\text { ( } \mu \text { mol) }\end{array}$} \\
\hline & Mean & SD & Mean & SD & Mean & SD \\
\hline $\begin{array}{l}\text { Toluene, } 2 \mathrm{mg} \cdot \mathrm{min}^{-1} \\
\text { Toluene, } 2 \mathrm{mg} \cdot \mathrm{min}^{-1}+\text { ethanol } 0.08 \mathrm{~g} \cdot \mathrm{kg}^{-1} \\
\text { Toluene, } 2 \mathrm{mg} \cdot \mathrm{min}^{-1}+\text { ethanol } 0.16 \mathrm{~g} \cdot \mathrm{kg}^{-1} \\
\text { Toluene, } 2 \mathrm{mg} \cdot \mathrm{min}^{-1}+\text { ethanol } 0.32 \mathrm{~g} \cdot \mathrm{kg}^{-1} \\
\text { Control } \\
\text { Control + ethanol, } 0.32 \mathrm{~g} \cdot \mathrm{kg}^{-1}\end{array}$ & $\begin{array}{r}45 \\
217 \\
1085 \\
2514 \\
-\end{array}$ & $\begin{array}{c}36 \\
29^{a} \\
437^{a} \\
1832^{a} \\
.\end{array}$ & $\begin{array}{l}3.22 \\
2.05 \\
3.53 \\
1.18 \\
0.81 \\
0.72\end{array}$ & $\begin{array}{l}1.91 \\
1.50 \\
1.71 \\
0.91^{b} \\
0.71 \\
0.29\end{array}$ & $\begin{array}{l}1.65 \\
1.72 \\
1.23 \\
1.83 \\
0.29 \\
0.30\end{array}$ & $\begin{array}{l}1.01 \\
0.95 \\
0.66 \\
0.89 \\
0.17 \\
0.12\end{array}$ \\
\hline
\end{tabular}

a The values are different from those above $(p<0.01)$.

the excretion rate is lower than the other three rates $(p<0.05)$.

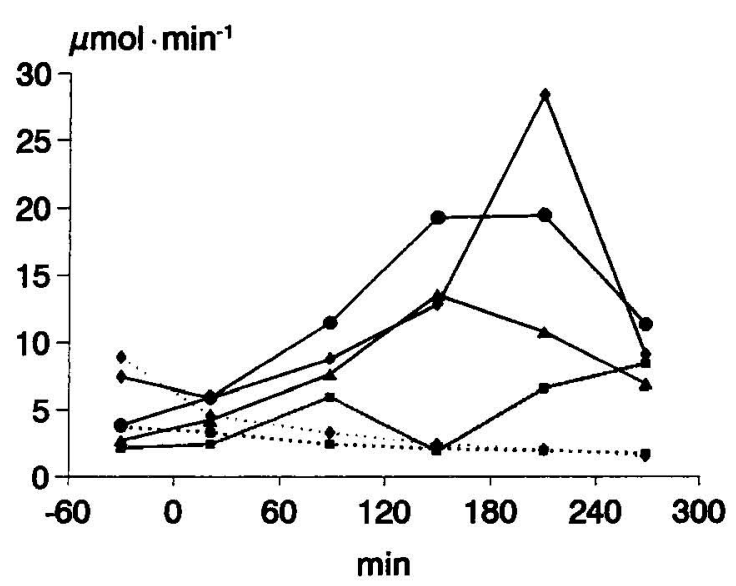

Figure 6. Excretion rate of hippuric acid $(\mathrm{HA})$ during the six different exposures in study $B$. The curves show the average of four subjects. $\left(-=2 \mathrm{mg} \cdot \mathrm{min}^{-1}\right.$, no ethanol; $\Delta-\cdots=2 \mathrm{mg} \cdot \mathrm{min}^{-1}, 0.08 \mathrm{~g} \cdot \mathrm{kg}^{-1}$ ethanol; $\bullet-2 \mathrm{mg}$. $\mathrm{min}^{-1}, 0.16 \mathrm{~g} \cdot \mathrm{kg}^{-1}$ ethanol; $\cdot-\mathbf{- 1}=2 \mathrm{mg} \cdot \mathrm{min}^{-1}, 0.32 \mathrm{~g}$. $\mathrm{kg}^{-1}$ ethanol; $\cdots \cdot=$ control, no ethanol; $\cdots \cdot \cdot=$ control, $0.32 \mathrm{~g} \cdot \mathrm{kg}^{-1}$ ethanol)

measurement after $3 \mathrm{~h}$ of exposure. At this time the concentration was $3.2(\mathrm{SD} 3.7) \mathrm{mg} \cdot \mathrm{m}^{-3}$.

Ingestion of an ethanol dose of $0.08 \mathrm{~g} \cdot \mathrm{kg}^{-1}$ caused a transient increase in alveolar toluene concentration with a maximum of 4.9 (SD 3.2$) \mathrm{mg} \cdot \mathrm{m}^{-3}$ after $30 \mathrm{~min}$. After ingestion of 0.16 or $0.32 \mathrm{~g} \cdot \mathrm{kg}^{-1}$ an increase in alveolar concentration was detected after $10 \mathrm{~min}$, when only one-third of the dose had been given. The increase continued for $60 \mathrm{~min}$ to 23.7 (SD $11.0) \mathrm{mg} \cdot \mathrm{m}^{-3}$ when $0.16 \mathrm{~g} \cdot \mathrm{kg}^{-1}$ was given and was followed by a sharp decrease.

At a dose of $0.32 \mathrm{~g} \cdot \mathrm{kg}^{-1}$ the increase in alveolar toluene concentration continued for at least $90 \mathrm{~min}$ to 38.9 (SD 28.2) $\mathrm{mg} \cdot \mathrm{m}^{-3}$. Up until $60 \mathrm{~min}$ after the ethanol dose administration there was no difference in the alveolar toluene concentration for the doses $0.16 \mathrm{~g} \cdot \mathrm{kg}^{-1}$ and $0.32 \mathrm{~g} \cdot \mathrm{kg}^{-1}$.

The excretion of HA is shown in figure 6. An ethanol dose of $0.32 \mathrm{~g} \cdot \mathrm{kg}^{-1}$ decreased the HA excretion by 37 (SD 8$) \%$ and 84 (SD 19)\% in the first and second sample, respectively, after the ingestion of ethanol. The lower doses of ethanol had no effect on the HA excretion, and there was no effect of ethanol on HA during the control exposure. The $o$-cresol excretion was not significantly affected by the ingestion of ethanol. The HA excretion with the rates during the control exposure subtracted was 73 (SD 48)\% of the ingested toluene. One subject had a $65 \%$ lower HA excretion and a $82 \%$ lower $o$-cresol excretion than the other three.

Except for slight nuisance from the tube, no complaints of any side effects were issued by the subjects during the experiment; especially, no gastrointestinal symptoms were recorded.

\section{Discussion}

In the present study the alveolar concentration of a solvent was used as an estimate of the hepatic extraction ratio of the intact liver. However, the alveolar concentration was also influenced by the uptake of toluene from the gastrointestinal channel and by the distribution in the body.

The gastrointestinal uptake could only be estimated by the excretion of HA. This measure is crude because of the large and varying background excretion. Besides, a fraction of the toluene is deposited in the muscles and adipose tissues.

In study A the estimated uptake was about $100 \%$, but in study B one subject had a much lower metabolite excretion than the others. This incomplete uptake may represent a problem for the interpretation of the results, but fortunately the uptake seems to be relatively constant for each subject. In studies in which weaker interactions are studied, this variation would be important, and the use of tracers or substances with more specific metabolites would then be preferable. The bolus exposure given when the toluene metabolism was inhibited provided an idea of the time course of the gastrointestinal uptake. Ethanol, however, decreased the gastrointestinal motility and the liver blood flow and may have therefore delayed the uptake of toluene. The results, however, indicate, that steady state is probably obtained within $1 \mathrm{~h}$ after the start of exposure.

Alveolar concentration of toluene is usually considered to be proportional to the arterial concentra- 
tion and therefore reflects the concentration in the central compartment of the body (1). This concentration is built up by the inflow from the hepatic vein and recirculation from other compartments. The amount which is exhaled or distributed to muscles and adipose tissue decreases the concentration. This phenomenon gives a complicated relation between the toluene concentration in the hepatic vein and in the alveolar air. To describe this occurrence, a physiologically based pharmacokinetic model is preferable.

The hepatic extraction ratios calculated from study A were extremely high. The calculation gave a crude estimate of the average ratio, and the value may be an overestimation because the relative contribution of extrahepatic metabolism may be important at these very low toluene concentrations.

However, the high extraction ratio and the drastic decrease observed when the dose rate was tripled suggest a complicated metabolic model for toluene. The results are in agreement with the sinusoidal perfusion or parallel tube model of the liver, and toluene behaves very much like ethanol in very low doses (13). The widely used "well-stirred model," on the other hand, cannot explain the phenomenon (12). From the actual results the metabolic constants of toluene cannot be estimated.

Ethanol had a very dramatic effect on toluene metabolism. An effect was seen almost immediately after the ingestion of about $4 \mathrm{~g}$ of ethanol, and the length of the inhibition increased with the ethanol dose. The initial increase in alveolar toluene concentration was not altered by an increase in the ethanol dose from 0.16 to $0.32 \mathrm{~g} \cdot \mathrm{kg}^{-1}$. This finding indicates that even at a low blood alcohol concentration the metabolism of toluene is maximally inhibited. Therefore a single alcohol drink maintains a maximal inhibitory effect on the hepatic elimination of toluene. The dose-related decrease in HA excretion is then an expression of the longer duration of metabolic inhibition. The alcohol dose necessary to produce this degree of inhibition is clearly lower than that estimated from studies in which toluene was administered by inhalation $(14-16)$. Ethanol mainly inhibited the major metabolic pathway, side-chain oxidation, while the minor pathway, ring oxidation, seemed to be less affected. However, the toluene concentration was considerably higher when ethanol was given, and the ingestion of larger doses of ethanol decreases $o$-cresol excretion too (15).

The results of our study seem to indicate that the method of administering an organic solvent gastrointestinally is sensitive to even small doses of an interacting factor or to factors with low interacting potentials on solvents with a high liver clearance. The method measures relative changes in the extraction ratio. The alveolar concentration, however, also reflects the distribution and recirculation of the solvent. Therefore development of a pharmacokinetic model is required to interpret the results quantitatively with an estimation of the metabolic constants of toluene and the model of interaction. However, the advantage of the method, in comparison with that of conventional inhalation studies, is the relatively simple setup, no nuisance for the subjects, a more specific focus on the central role of the liver, and better temporal resolution.

\section{Acknowledgments}

The experiment was skillfully conducted by laboratory technicians Ms K Westergaard and Mr S Rokny, while the analysis of the metabolites was skillfully carried out at the Laboratory of the Medical Department F, Copenhagen County Hospital, in Gentofte by laboratory technician Ms S Hjerpsted.

The study was supported by the Danish Medical Research Council (grant no 12-8444), the Health Insurance Foundation (grant no 11/265-88), and the Research Foundation of the University of Aarhus.

\section{References}

1. Fiserova-Bergerova V, ed. Modeling of inhalation exposure to vapors: uptake, distribution, and elimination; vol I. Boca Raton, FL: CRC Press, 1983.

2. Bælum J. Human solvent exposure: factors influencing the pharmacokinetics and acute effects. Pharmacol Toxicol 1991;68 suppl 1.

3. Fiserova-Bergerova V. Toxicokinetics of organic solvents. Scand J Work Environ Health 1985;11 suppl $1 ; 7-21$.

4. Wallén M, Holm S, Byfält Nordqvist M. Coexposure to toluene and p-xylene in man: uptake and elimination. Br J Ind Med 1985;42;111-6.

5. Riihimäki K, Savolainen K, Pfäffli P, Pekari K, Sippel HW, Laine A. Metabolic interaction between $\mathrm{m}$ xylene and ethanol. Arch. Toxicol 1982;49;253-63.

6. Dick RB, Setzer JV, Wait R, et al. Effects of acute exposure of toluene and methyl ethyl ketone on psychomotor performance. Int Arch Occup Environ Health 1984;54:91-109.

7. Pyykkö K, Tähti H, Vapaatalo H. Toluene concentrations in various tissues of rats after inhalation and oral administration. Arch Toxicol 1977;38;169—76.

8. Åstrand I, Ehrner-Samuel H, Kilbom Å, Övrum P. Toluene exposure: I. concentration in alveolar air and blood at rest and during exercise. Work Environ Health 1972;9;119-30.

9. Carlsson A. Exposure to toluene: uptake, distribution and elimination in man. Scand $\mathbf{J}$ Work Environ Health $1982 ; 8 ; 43-55$.

10. Opdam JJG, Smolders JFJ. Alveolar sampling and fast kinetics of tetrachloroethene in man: I. alveolar sampling. Br J Ind Med 1986;43;814-24.

11. Hansen SH, Døssing M. Determination of urinary hippuric acid and o-cresol, as indices of toluene exposure, by liquid chromatography on dynamically modified silica. J Chromatograph 1982;229;141-8.

12. Rowland M, Tucker G, ed. Pharmacokinetics: theory and methodology: international encyclopedia of pharmacology and therapeutics; vol. 122. Oxford: Pergamon Press, 1986.

13. Keiding $S$, Johansen S, Rabøl A, Christensen L. Ethanol elimination kinetics in human liver and pig in vivo. Am J Physiol 1979;237;E317-24.

14. Waldron HA Cherry N, Johnston JD. The effects of ethanol on blood toluene concentrations. Int Arch Oc- 
cup Environ Health 1983;51;365-9.

15. Døssing M, Bælum J, Hansen SH, Lundqvist GR. Effect of ethanol, cimetidine and propranolol on toluene metabolism in man. Int Arch Occup Environ Health $1984 ; 54 ; 309-15$.

16. Wallén M, Johanson G, Byfält Nordqvist $M$. The ef- fects of ethanol on the kinetics of toluene in the perfused rat liver. Toxicol Lett 1985;26;59—64.

Received for publication: 13 March 1992 